\title{
Applicability of Performance Prism in SMEs: a multiple case study
}

\section{Aderência do Performance Prism em MPE's: um estudo de casos múltiplos}

GESTÃO PRODỨC̄̃O

ISSN 0104-530X (Print) ISSN 1806-9649 (Online)

\author{
Elizandra Severgnini ${ }^{1}$ (i) \\ Edwin V. Cardoza Galdamez ${ }^{1}$ \\ Reinaldo Rodrigues Camacho'
}

How to cite: Severgnini, E., Cardoza Galdamez, E. V., \& Camacho, R. R. (2019). Applicability of Performance Prism in SMEs: a multiple case study. Gestão \& Produção, 26(4), e3014. https://doi.org/10.1590/0104-530X3014-19

\begin{abstract}
In the performance assessment models literature, is rather rare research that discusses the Performance Prism Framework, specifically in using it as management tool and in checking its validity as driver strategy instrument. There are also few studies on the applicability related to the implementation, use and analysis of the Performance Prism Framework in micro and small businesses. In this sense, this article has as main objective to propose (i) a bibliometric study of the Performance Prism Framework; and (ii) to develop a multiple case study of micro and small business. To meet the first goal, we used a bibliometric desk research method in the major databases, such as ISI Web of Knowledge, EBSCO and Proquest, which generated 81 articles. From them, we analyzed specifically few studies. To achieve the second goal, a multiple case study method with five micro and small businesses (e.g., sports segments, drugstore, clothing, department store and an apparel faction) was held. The findings confirmed the five dimensions of the Performance Prism Framework, called: (1) Stakeholders Satisfaction; (2) Contribution of Stakeholders; (3) Strategies; (4) Processes; and (5) Capabilities. In addition, we extend previous literature and proposed another dimension called (6) Performance Dynamic. The results also showed that the Capabilities is strongly seen as training employees, the Performance Dynamics are fundamentally weighted as sales amount, not as profit and the Contribution of Stakeholders is hardly evident.
\end{abstract}

Keywords: Small and medium enterprise; Performance measurement system; Performance Prism.

Resumo: Na literatura sobre os modelos de avaliação de desempenho organizacional, são um tanto raras as pesquisa sobre o Performance Prism (PP), especialmente quanto ao seu uso como ferramenta de gestão e sua validade como instrumento direcionador da estratégia. Também são escassos os estudos sobre a aplicabilidade das pesquisas relacionadas à implementação, análise, uso e até mesmo manutenção do PP em micro e pequenas empresas. Com base nesse gap, este estudo tem por objetivo principal realizar i) um estudo bibliométrico do PP; ii) desenvolver estudos de casos múltiplos de micro e pequenas empresas quanto à observação e adequação das organizações ao modelo. Para atender o primeiro objetivo, uma pesquisa bibliométrica tipo desk research foi realizada nas principais bases de dados do ISI Web of Knowledge, EBSCO, e Proquest. A pesquisa gerou uma base de 81 artigos, sendo que alguns estudos se encaixaram no escopo desta pesquisa. Para atingir o segundo objetivo, um estudo de caso múltiplo com cinco micro e pequenas empresas (nos segmentos de esportes, farmácias, confecções, loja de departamentos e uma facção) foi realizado. Os achados da pesquisa mostraram as cinco facetas do PP, denominadas: 1) Satisfação dos Stakeholders; 2) Contribuição dos Stakeholders; 3) Estratégias; 4) Processos; e 5) Capacidades. Além disso, os achados apresentaram uma nova dimensão denominada de 6) Desempenho. Os resultados também demonstraram que o quesito de Capacidades é fortemente visto como treinamento de colaboradores, que a Dinâmica de Desempenho é fundamentalmente ponderada como volume de vendas e não como lucro e que a Contribuição dos Stakeholders para o negócio é pouco evidenciada.

Palavras-chave: MPE's; Medição de desempenho; Performance Prism.

${ }^{1}$ Programa de Pós-graduação em Ciências Contábeis - PCO, Departamento de Ciências Contábeis, Universidade Estadual de Maringá UEM, Av. Colombro, 5790, Bloco C-23, CEP 87020-900, Maringá, PR, Brasil, e-mail: elisevergnini@gmail.com; evcgaldamez@uem.br; rrcamacho@uem.br

Received Mar. 21, 2016 - Accepted Jan. 6, 2017

Financial support: None. 


\section{Introduction}

The concept and application of the Performance Measurement System (PMS) has become a key point in organizational management over the years (Choong, 2013). PMS is an old and extremely relevant issue in the field of accounting, administration and engineering, since it implements actions in the pursuit of market objectives and strategies (Lebas, 1995). This search occurs because the organization needs to observe different perspectives to measure its performance, to gauge results periodically and to elaborate a systematics of system feedback in a constant way.

Several PMS models have been developed in recent years and are widely discussed in the literature as tools to leverage performance, such as Balanced Scorecard (Kaplan \& Norton, 1992), the SMART (Cross \& Lynch, 1990), the performance measurement questionnaire (Dixon et al., 1990), the Cambridge Process Design (Neely et al., 1995) and the integrated performance measurement model (Bititci et al., 1998).

After analyzing the various models of PMS, Neely et al. (2001) suggest an alternative called Performance Prism (PP). For Neely et al. (2002), the PP brings three major advances when compared to other proposals, and the model: 1) it focuses on more than one stakeholder group, since previous models focus on at most one or two groups (Shareholders and Clients); 2) it does not ignore the chance to align strategies, processes and capabilities in line with stakeholder interests; and 3) aligns not only the shareholders' expectations with the company, but also includes the reverse. Therefore, there seems to be a clear contribution to the PP proposal for management (Najmi et al., 2012), although little is known about its adherence to Micro and Small Enterprises (SMEs).

Thus, there are four gaps still unfilled in the literature. First, given the existence of criticism of Balanced Scorecard (Basso \& Pace, 2003; Norreklit, $2000)$, the PP is proposed as a relevant advance for business management, lacking an empirical examination. Second, several organizations adopt only the traditional financial performance measures (Tangen, 2004; Kaplan \& Norton, 2001) and that the PP goes beyond them, generating the need to advance in the way the model empirically measures these different results. Third, due to the need for new measures that escape non-financial measures (Pun \& White, 2005), and how PP uses non-objective measurement metrics as the stakeholder (Liu et al., 2015), there is a possibility of advancement in the adherence of the tool to the business practice. Fourth with few exceptions (Cocca \& Alberti, 2010; Taticchi et al., 2008; Hudson et al., 2001), there is a clear lack of studies that verify how SMEs use the PMS, even more sophisticated ones such as PP.

A multi-case study on SMEs observing the behavior and adherence of the PP can scientifically evidence the variables related to the use and to advance in the literature in question. Thus, based on the wide range of studies cited that employ PMS (Najmi et al., 2005), the need for companies to apply new tools to measure the result and the alternative model of Neely et al. (2001), this work has as main objective to perform i) a bibliometric study of PP and ii) verify the adherence of the model through a multiple case study in SMEs.

The proposed bibliometric research on PP is aligned with the efforts made by different authors in the field of knowledge organization in accounting, such as the bibliometric works of Grzebieluckas et al. (2008), Faro \& Silva (2008) and Silva \& Souza-Coelho (2007). The continuity of the bibliometric survey is also important, since there is a wide range of publications (Braz et al., 2011) and it becomes complicated to follow the evolution of knowledge, the dissemination of new publications on the subject and the ability to apply new perspectives of performance evaluation in the field of accounting, thus generating need for knowledge organization.

The present research discusses the use of PMSs in SMEs (Cocca \& Alberti, 2010; Bourne et al., 2000,2002 ) and for this it employs a multiple case study investigation, asking the owners about the use of the different dimensions of the PP. In this sense, field research with multiple cases provides useful information for understanding how business people observe and measure stakeholder, capabilities, strategy, and process issues. The next section highlights basic theory. Then the methodology is presented and the results are discussed.

\section{Theoretical background}

\subsection{Performance Measurement Systems (PMS) in SMEs}

Performance measurement has been shown, especially in the last two decades, as a critical condition for the efficiency and effectiveness of any business, facilitating effective control and correction by comparing current performance results with desired performance levels (Melnyk et al., 2014; Taticchi et al., 2010). However, some research has shown that traditional and contemporary PMS models are configured for use in medium- and large-company contexts and that SMEs have distinct characteristics that differentiate them from most large companies (Hudson et al., 2001; Garengo et al., 2005).

The investigation of these particular characteristics of SMEs showed a favorable context for the implementation of the PMS, given the growth of the competitive environment and the propensity for development, evolution of the concept of quality, increased focus on continuous improvement and significant development of information technology (Garengo et al., 2005). The key characteristics of 
SMEs that differentiate them from the medium and large companies pointed out by Hudson et al. (2001) were: $i$ ) customized management; $i$ i) serious resource constraints in terms of management and workforce, as well as financial; iii) dependence on a small number of customers and operation in limited markets; iv) flexible structures; $v$ ) high innovative potential and $v i$ ) informality and dynamic strategy.

In addition to the particularities found in SMEs, Taticchi et al. (2008) highlight five shreds of evidence in the literature on how SMEs have conditions to manage an PMS. The first is that most SMEs have some accounting control to support monitoring. Second, the owners or managers have a good local market knowledge and are aware of the demands of customers. Third, when compared to large companies, SMEs have more intense relationships with customers, generating more frequent post-sales services. Fourth, the degree of bureaucracy and line of communication is smaller, increasing speed in problem solving and decision making. Finally, the fifth is the fact that SMEs are dedicated to specific market niches, making it easier to focus on select clients and satisfying them with customized products and services.

Few studies have been concerned in analyzing how the implementation of PMS occurs in SMEs (Taylor \& Taylor, 2014; Silvi et al., 2015). Still, in the surveys, there are indications of ambiguity in the results that compare the effectiveness of PMS in small and large companies. Taylor \& Taylor (2014) evaluated the influence of the size of 349 English companies on the effectiveness of the PMS implementation, concluding that the practices that allow the execution of PMS in large companies are not necessarily the same in SMEs and vice versa. Conversely, Silvi et al. (2015) tested 88 firms in Italy if size influenced the implementation and choice of the PMS model and the result rejected the hypothesis. Therefore, the research gap that demonstrates the influence of the size of companies in relation to the choice, implementation, use and revision of the PMS needs further investigation.

The PMS models, considered the new generation that takes into account the integration of performance measures, financial and non-financial indicators, have gained great notoriety in the research, mainly the Kaplan \& Norton (1992) Balance Scorecard (BSC) model. However, a study of industries in Canada showed that $70 \%$ of companies failed to implement the BSC (Gosselin, 2005). Rompho (2011) pointed out that the main cause of the failure to implement the BSC in a SMEs is the company's frequent change of strategy, which needs rapid responses to changes, unlike large organizations that operate in more stable markets.

Finally, Garengo et al. (2005), when analyzing eight PMS models, pointed out some limitations of the BSC for SMEs, since the same: $i$ ) does not take into account the wishes and demands of all Stakeholders involved; ii) has difficulty adapting to a dynamic environment, which requires periodic review of performance measures; iii) lack of simplicity and clarity in the methodology, measures and objectives defined; $i v$ ) the analysis of the processes is partially met and, finally, v) the model follows a fully verticalized proposal, that is, hierarchical and focused on cost performance, until the activity becomes economically financial.

However, other PMS proposals can overcome the limitations of the BSC presented earlier. One of them is the PP that will be reported in the section itself.

\subsection{Performance Prism (PP)}

The PP is an innovative performance measurement model introduced by Adams \& Neely (2000) in response to criticisms of the Balanced Scorecard and the shortcomings of many other models, being considered as the second generation of PMS (Neely et al., 2001). The PP seeks to differentiate itself from other PMS models, such as the BSC, offering a unique perspective of adopting a model as a way to operationalize it as a whole in the company, rather than just measuring the performance of the organization (O'Boyle \& Hassan, 2013). Moreover, the PP takes into account that the starting point is to understand the determinants of values for a company, that is, the factors that create values for the Stakeholders. Once stakeholders are known and identified, these factors will determine which measures contribute to long-term success and then how to translate organizational objectives into measures that will guide the actions of managers (Neely et al., 2002).

In Neely et al. (2001), there is a misunderstanding as to the correct timing of formulating company strategies, which are usually drawn in the foreground and after structuring, performance measures are established. For the authors, the performance measures serve to focus on the destination that managers want to achieve, while the strategies represent a guide of how they will achieve the desired destination. Therefore, the strategy-measurement formulation should be the opposite (Neely et al., 2001), pondering the necessary points and then defining the organizational strategy.

Based on the relationship measurement-strategy, the PP is represented by a geometric figure of prism, containing five facets. Each of the faces of the prism is responsible for answering different organizational issues, considered fundamental so that managers can evaluate the true scope of the problems in the performance management of the organization (O'Boyle \& Hassan, 2013). The questions that represent each of the faces of the PP are described below, according to the proposal of Neely et al. (2002):

a) Stakeholder satisfaction - Who are the company's stakeholders and what do they want and need? 
b) Strategies - What strategies does the company have to put in place to meet stakeholder needs?

c) Processes - What are the critical processes required to carry out these strategies?

d) Capabilities - What capabilities does the company need to operate and improve these processes?

e) Contribution of Stakeholders - What contributions does the company want from stakeholders to maintain and develop those capabilities?

According to da Silva et al. (2013, p. 138),

$[\ldots]$ the idea behind PP is that, although there are systems with financial and non-financial measures, such as the Balanced Scorecard itself, there are a need for a second generation performance measurement models to assist organizations in updating and / or developing scorecards that are appropriate to the demands of the competitive environment, putting stakeholder interests first.

The first application of the PP was carried out at the company DHL International, unit of England by Andy Neely and his group of researchers from the Center for Business Performance of the Cranfield School of Management (UK) in mid-1999. DHL's board and board members were dissatisfied with the company's performance appraisal. In addition, concern began to arise about issues related to how appropriate the structure and strategic focus of the business for business growth and complexity for the 21 st century.

DHL implemented the PP to identify criteria that would create levels of satisfaction to the Stakeholders and the possible returns that this would generate for the total operations of the company. Through workshops with the board and directors, stakeholder segmentation within subgroups was undertaken to customize services using strategy, process, and capabilities perspectives. Moreover, the PP was useful for generating the analysis of the needs of the management teams, directing the most appropriate decision making for the business, as well as shaping the whole DHL culture. After one year of implementation of the PP, DHL achieved significant gains in performance and management skills, in addition to claiming that quality measures were able to provide adequate responses and clarity in the information for each group of stakeholders.

Two studies were found with the PP implementation process in higher education institutions (Singh \& Weligamage, 2010; Smulowitz, 2015). The first one concluded that the implementation of PP was highly beneficial for the academic institution and that the process should start from identifying the needs of the stakeholders and then formulating the strategies using the existing capabilities to offer a better value to all. Already, in Smulowitz's (2015) study, the identification of the neglect by the directors of the institution in identifying the wishes and needs of the Stakeholders was a key factor of failure in the effort of the planning of organizational change and with the PP, the chances of success would be larger.

Chillida (2009) elaborated a theoretical analysis on the application of PP in SMEs and concluded that PP is a useful tool for the allocation of limited resources, allowing companies to obtain the best possible performance due to environmental changes. Chillida's (2009) research considers SMEs to improve business performance by creating stakeholder satisfaction, creating a solid foundation for engagement and retention of relationships in a simpler way.

A case study of multiple cases was carried out by Severgnini et al. (2017), analyzing how the perception of the satisfaction and contribution of the Stakeholders by the managers of companies occurs. The company evidenced the understanding on the part of the seven managers that there is understanding about who the Stakeholders are and what is expected of them. However, the study did not address whether there are strategies, processes and capabilities that meet those needs and desires.

Finally, in a comparative analysis of the PMS models, Garengo et al. (2005) evaluated ten criteria that make a PMS model adequate to the reality of SMEs: strategic alignment, strategy development, focus on Stakeholders, multidimensional (balanced) measures, dynamic adaptability, process orientation, depth and breadth, causal relationships and simplicity and clarity. Among the comparisons, the PP was the only model that met all these criteria. Moreover, for Garengo et al. (2005), PP is part of the new generation of systems, which are structured on a horizontal basis, that is, processes and relationships in the value chain. Therefore, considering the presentations of PP implementations and studies that argue the benefits and advantages of its applicability in SMEs, it is suggested that, through a multi-case study, PP adherence in SMEs should be studied.

\section{Research design}

The evaluation of performance is constantly discussed, and in a Google Scholar search we find $35,400,000$ results with the English term (search on December 2, 2016). Therefore, there is a wide range of papers, theoretical perspectives, models, empirical results and distinct applications for management. Notwithstanding, the use of PMS in accounting has been gaining space and relevance in academia.

Specifically, the texts of Govindarajan (1984) and Hopwood (1972) are two examples of the wide application of performance evaluation, both cited more than 570 and 834 times in Google Scholar.

These data show not only the relevance of the theme but also justify the choice of the method for 
the elaboration of this work. The method is divided into two parts. First, the systematics of bibliometrics is explained. Subsequently, the systematics of the multiple case study is discussed.

\subsection{Bibliometrics}

This study, in part, is characterized as bibliometric and descriptive, using the Web of Science as a way of selecting the works. It is bibliometric because it uses "cienciometry" or "cienometry", "[...] which aims to generate information and discussions that contribute to overcoming the challenges characteristic of modern science" (Santos, 2004, p. 23).

For the present research, the Web of Science (or ISI) base was adopted as a data source. The Web of Science is an online scientific citation and indexing database maintained by the Thomson Reuters group. The database gives access to multiple databases that cross-reference research, allowing you to explore various academic and scientific papers.

In order to carry out the research, the following terms were used in the database, being P1: Topic $=$ ("performance prism") and P2: Topic $=(" A n d y$ Neely"). The research generated 81 articles with the combinations of terms used.

\subsection{Case study}

Field research is a multiple case study (Stake, 1978), as it investigates in depth five micro and small enterprises as study phenomena. In order to meet the nature of the objective of this research, the type of case study is interpretative, since

[...] it seeks to describe in detail a phenomenon studied and to find patterns in the shreds of evidence, developing conceptual categories that make it possible to illustrate, confirm or oppose theoretical assumptions (Silva et al., 2010, p. 124).

For qualitative research, Seawright \& Gerring (2008) suggest the random search for several companies. Thus, five SMEs were selected and the number of cases was defined by saturation, making possible the comparison and the robustness of the evidence (Silva et al., 2010).

For the selection of cases, the criterion of several cases was adopted, seeking to contrast different organizational dynamics and "[...] encompass a wide variation to reinforce the representativeness of the sample of selected cases" (Seawright \& Gerring, 2008, p. 301). The selection was made based on the following criteria: (1) sports retail; (2) drugstore; (3) department retail; (4) clothing retail; and (5) apparel faction, how to provide services in the B2B. The criterion of selection of the studies meets the requirements of Curtis et al. (2000, p. 1002), being "[...] sequential by a rolling process".

At the evidence gathering stage, five face-to-face interviews were conducted with company managers and transcribed in form. The open semi-structured interview script follows the proposal of Neely et al. (2001) with five questions to evaluate the five dimensions of the PP. In order to understand and interpret managers' perceptions regarding the adherence of the model, this method of collection was chosen because "[...] it allows to obtain a wealth of information, to provide the researcher with the opportunity to clarify and follow up questions and answers in a direct and flexible interaction" (Silva et al., 2010, p. 306). Table 1 presents the research constructs, as well as their purposes, which are referenced in the works of Neely et al. (2002).

Table 1. Constructs of the research.

\begin{tabular}{|c|c|c|}
\hline Constructs & Questions & Objective \\
\hline $\begin{array}{l}\text { Stakeholder } \\
\text { satisfaction }\end{array}$ & $\begin{array}{l}\text { In your opinion who are the most important } \\
\text { people or institutions for the operation of your } \\
\text { company? }\end{array}$ & $\begin{array}{l}\text { Grasp the managers' understanding of the } \\
\text { recognition of who are the main stakeholders } \\
\text { that generate value for their business. }\end{array}$ \\
\hline Strategies & $\begin{array}{l}\text { What strategies should the company put in } \\
\text { place to ensure stakeholders' wants and needs? }\end{array}$ & $\begin{array}{l}\text { Identify whether the company's strategies are } \\
\text { aligned to meet the needs and expectations } \\
\text { pointed out by Stakeholders, as well as the } \\
\text { desires in the company's results. }\end{array}$ \\
\hline Processes & $\begin{array}{l}\text { What processes does the company need to put } \\
\text { into practice to enable them to implement the } \\
\text { strategy? }\end{array}$ & $\begin{array}{l}\text { Identify if the processes implemented, fulfill } \\
\text { the execution of the strategy (e.g. quality, time } \\
\text { of integration). }\end{array}$ \\
\hline Capabilities & $\begin{array}{l}\text { What capabilities does the company need } \\
\text { to have to enable the operation of all these } \\
\text { processes? }\end{array}$ & $\begin{array}{l}\text { Identify if the combination of people, practices, } \\
\text { technology and infrastructure allows creating } \\
\text { value in the processes for Stakeholders. }\end{array}$ \\
\hline $\begin{array}{l}\text { Contribution of } \\
\text { Stakeholders }\end{array}$ & $\begin{array}{l}\text { As a company manager, what do you want from } \\
\text { these people or institutions? }\end{array}$ & $\begin{array}{l}\text { Know the understanding of the managers } \\
\text { about the clarity as the return that one has or is } \\
\text { expected of the main Stakeholders involved. }\end{array}$ \\
\hline
\end{tabular}

Source: Adapted from Neely et al. (2002). 
In the analysis of evidence is used the technique of narrative analysis of the gnoseological type whose "[...] succession of events is of less importance than the perception one has of them, of the degree of knowledge one has or can obtain from them" (Silva et al., 2010, p. 410).

The choice of the technique of narrative analysis allows the analysis of different ways after capturing and transcribing the evidence since it involves fundamental characteristics to understand the not said (Muylaert et al., 2014). In addition to the narratives, we also obtained access to some information through documentary analysis (e.g. sales report, expenses report, notes in notebooks, analysis of customer records) and by observation (e.g. one hour of follow-up of the work in each one of companies, where it was possible to analyze how the calculation of the indicators was elaborated), allowing to evaluate the degree of veracity of what was said. The analysis of the narratives was carried out in four phases: 1) organization: ordering of transcripts, according to the semi-structured script;
2) floating reading: search for preliminary knowledge of narratives; 3) exploration of the material: the moment of refining the narratives to generate comprehension of the text, in a more detailed way, being guided by the methodology defined; and 4) treatment of evidence: inference and interpretation of narratives.

\section{Results}

\subsection{Bibliometric analysis}

A total of 81 articles were found using the search terms previously described. Of these articles, 46 (57\%) were excluded because they did not have in the title and in the abstract, both conditions, the terms of Performance Assessment or Micro and Small Business. Thus, 35 (43\%) articles remained. Other texts were excluded, because even using the title and the abstract the terms, only made mention within the text, not working with the phenomenon in question.

Table 2 highlights the results of the bibliometric analysis of the main performance evaluation texts in

Table 2. Top 5 main articles by Prof. Andy Neely (University of Cambridge) through Google Scholar citation.

\begin{tabular}{|c|c|c|c|}
\hline Article title & $\begin{array}{l}\text { Citations } \\
\text { Google } \\
\text { scholar }\end{array}$ & $\begin{array}{c}\text { Web of } \\
\text { Science }\end{array}$ & Highlights \\
\hline $\begin{array}{l}\text { Performance } \\
\text { measurement system } \\
\text { design: a literature review } \\
\text { and research agenda } \\
\text { (Neely et al., 2005) }\end{array}$ & 2.632 & 109 & $\begin{array}{l}\text { The article discusses the state of the art of PMS. The concept } \\
\text { presented is "performance measurement is the process of } \\
\text { quantifying the effectiveness and efficiency of an action" (p. } \\
\text { 1229). For authors, performance can be analyzed by quality, } \\
\text { time, flexibility and cost. It ends by discussing organizational and } \\
\text { environmental performance (internal vs. external). }\end{array}$ \\
\hline $\begin{array}{l}\text { The performance } \\
\text { measurement revolution: } \\
\text { why now and what next? } \\
\text { (Neely, 1999) }\end{array}$ & 1.061 & 201 & $\begin{array}{l}\text { The author discusses } 7 \text { reasons to measure performance: } \\
\text { 1) change in the nature of work; 2) increased competition; } \\
\text { 3) specific initiatives; 4) national and international awards; } \\
\text { 5) change in the organization's roles; 6) change in external } \\
\text { demands and 7) the power of information technology. The author } \\
\text { highlights the determinants, the benchmarking method, the } \\
\text { method of adoption and performance management. }\end{array}$ \\
\hline $\begin{array}{l}\text { State-of-the-art in } \\
\text { product-service systems } \\
\text { (Baines et al., 2007) }\end{array}$ & 968 & 209 & $\begin{array}{l}\text { The article discusses the state of the art of the product-service } \\
\text { system. The authors define the product-service concept, classify } \\
\text { the literature and the main findings in the theme. }\end{array}$ \\
\hline $\begin{array}{l}\text { The performance prism: } \\
\text { The scorecard for } \\
\text { measuring and managing } \\
\text { business success } \\
\text { (Neely et al., 2002). }\end{array}$ & 911 & NA & $\begin{array}{l}\text { The authors propose a model called Performance Prism. The } \\
\text { model integrates } 5 \text { perspectives: 1) stakeholder satisfaction } \\
\text { (e.g. value), 2) stakeholder contribution (e.g. from company } \\
\text { to managers and vice versa); 3) strategies (e.g. definitions of } \\
\text { strategies to meet the objectives); 4) processes (e.g. aligning } \\
\text { processes and functions between departments) and 5) capability } \\
\text { (e.g. employee skills, company policies, organizational } \\
\text { practices). The authors propose } 4 \text { fundamental processes for } \\
\text { the development of a PMS: design, planning and construction, } \\
\text { implementation and operation and feedback. }\end{array}$ \\
\hline $\begin{array}{l}\text { Designing, } \\
\text { implementing and } \\
\text { updating performance } \\
\text { measurement systems } \\
\text { (Bourne et al., 2000). }\end{array}$ & 886 & 187 & $\begin{array}{l}\text { The authors suggest a conceptual model analyze the } \\
\text { implementation of the performance evaluation system, using } 3 \\
\text { longitudinal case studies. The model has four phases (system } \\
\text { design, implementation of measures, use of measures to } \\
\text { implement the strategy and use of measures to change strategy) }\end{array}$ \\
\hline
\end{tabular}

NA = Not Available. Source: July 20, 2015. 
terms of the impact factor of the citation of Neely and his colleagues. The most relevant text discusses the state of the art performance measurement system, containing 2,608 citations in Google Scholar. The key text on the PP model is The performance prism: The scorecard for measuring and managing business success, published in 2002.

\subsection{Multiple case analysis}

Five companies were researched in this study, configuring a case study with multiple cases. The organizations are located in the Northwest region of Paraná. According to the questions used as guide for an interview, document analysis and observation, the total analysis of the evidence was performed.

Table 3 shows the organizations by the gender of the interviewee, the size of the company (billing criterion) and the time of operation. At the option of the authors, the companies are anonymous. The data show that on average there is an activity time of 13.20 years.

The first analysis is on the issue of Stakeholder Satisfaction. The PP model suggests that company stakeholder satisfaction shows how the organization aligns and ponders customer issues to seek profitability and return on assets.

The data showed that there is an intention to search for the measurement of customer satisfaction. We observe that the sports company does this search in an informal way, as it conducts a conversation with consumers, aiming to identify possible points of improvement in service. A critique of this response centers on the inability to create a measurable indicator of performance evaluation and that is comparable over time. Even if the sports company implements service management that meets the demands of customer satisfaction, it may not be possible to measure how much satisfaction there was of growth over time.

The Drugstore, in turn, hired a company that specializes in satisfaction research. Faced with this condition, the organization monitors the degree of satisfaction of its customers by outsourcing the service.
The last result of the customer satisfaction survey pointed to a result of $88 \%$ satisfaction. Therefore, there is a metric of performance evaluation and there is a periodic measurement, being congruent with the perspective of the model. Finally, the newly created clothing company employed the strategy of using Social Networks to promote its products and services, increasing contact and relationship with customers.

There is an informal survey of customer satisfaction, however, we held an informal conversation with the more known to identify possible points of improvement in treatment. As for the customers' demand, we seek to focus on products that meet the most different sports modalities offered in local schools and academies, such as: swimming, hydro, pilates, cycling, etc. [Dimension of Prism / Clients] (Sports Store).

\begin{abstract}
Annually we hire a company that specializes in satisfaction research and monitor the satisfaction of its customers. The last result showed a result of 8.8 satisfaction on a scale of 1 to 10 [Dimension of Prism / Clients] (Drugstore).
\end{abstract}

We conducted a satisfaction survey informally, interviewing clients during the visits to investigate how satisfied they are [Dimension of Prism/Clients] (Clothing).

There is an informal survey with customers, but according to the loyalty of more than 20 years and compliments we received, we believe that $80 \%$ of our customers are satisfied [Dimension of Prism / Clients] (Department Store).

The companies interviewed are also concerned with the organizational strategy. The PP considers the Strategies as the issues that the company needs to put into practice to meet the needs of stakeholders. Neely (2007) suggests that the strategy is something more complex in terms of where the company wants to go and what the value proposition is. For Neely et al. (2001), the key question in the strategy facet is: what strategies should the company put into practice to

Table 3. Cases analyzed in the multiple studies.

\begin{tabular}{cccccc}
\hline Variable & Alpha & Beta & Omega & Sigma & Zeta \\
\hline $\begin{array}{c}\text { Company } \\
\begin{array}{c}\text { Entrepreneur's } \\
\text { Gender }\end{array}\end{array}$ & $\begin{array}{c}\text { Sports } \\
\text { Male }\end{array}$ & $\begin{array}{c}\text { Drugstore } \\
\text { Female }\end{array}$ & $\begin{array}{c}\text { Clothing } \\
\text { Female }\end{array}$ & $\begin{array}{c}\text { Department Store } \\
\text { Male }\end{array}$ & $\begin{array}{c}\text { Apparel Faction } \\
\text { Male }\end{array}$ \\
$\begin{array}{c}\text { Firm Size } \\
\text { Time of }\end{array}$ & Micro & Small & Micro & Small & Small \\
$\begin{array}{c}\text { Existence (years) } \\
\text { Monthly revenue }\end{array}$ & 1 & 16 & 1 & 40 & 8 \\
& 6 thousand & Uninformed & 15 thousand & 100 thousand & 40 thousand \\
\end{tabular}

Source: Research data 2015. 
ensure stakeholders' wishes and needs? The drugstore has shown a strategy of offering special discounts, managing the price dynamics. Therefore, this is how the drugstore responds to the question. In this strategy, the great differential of the Network of Drugstore is to offer special discounts to members.

The sporting goods store also sought a strategy to leverage product mix, generating more options for customers. In addition, as a strategy to expand clients, the sports company has partnered with some academies, soccer fields and has adopted four channels of the disclosure. On the other hand, the apparel faction company, which has eight years of market, has the strategy to monitor the price of competitors and prioritize the quality of services provided. Some highlighted comments are presented below.

We have adopted the strategy of offering special discounts [larger] to all those customers who have the Network's assistance plan and in this way, we encourage consumption on the network. Our public is formed in the majority by customers who have the covenant of the Network. Our great differential is the special discounts to associates and the covenant made with medical clinics, which are offered as a partner to all registered clients [Dimension of the Prism / Unit] (Drugstore).

Recently, we expanded the product mix with supplements, given the demand by both the female and male public. The public is basically made up of students from academies or people who care about the well-being and routinely practice some physical activity. As a strategy to expand clients, we have partnered with some academies, soccer fields and adopted 4 channels of dissemination [Dimension of the Prism / Unit] (Sport Store).

As a strategy of expansion of clients, I made companies partnerships, offering discounts and invested in social networks [Dimension of Prism / Corporate and Media] (Clothing).

As a strategy, I have negotiated a higher price than the competition for prioritizing the quality of the services provided [Dimension of the Prism / Competitors] (Apparel Faction).

I know and follow the prices of competitors. Generally, it is the customer who sets the selling price. As a strategy, I prioritize the variety of product mix, offering my clients the possibility of finding everything they need [Dimension of the Prism / Competitors] (Department Store).

The process dynamics consider which are the critical processes required to carry out these strategies. According to Reame \& Reame (2007), the perspectives processes and aptitudes relate, respectively, to what processes are necessary to execute the strategies of the organization and what are the skills and conditions necessary to operationalize them, now and in the future, this through a combination of people, policies, procedures, technology and physical infrastructure.

Evidence shows that key points in the process are organizing inventory control and managing revenue, costs, and expenses. The first concerns the respondent's concern about production efficiency, controlling losses and wastes (as described below). The second concerns revenue. The third concerns the analysis of business operation and risk. It should be noted that some companies still do not have the stock control system, making it difficult to control this asset.

I have stock control of all products. I care about production efficiency, controlling losses and waste. Recently, I acquired a machine that rewinds lines and thus avoids the losses generated by unused line cones [Prism Dimension Processes / Planning and Management] (Apparel Faction).

I did price research and suppliers in major wholesale malls. There is no inventory control on the system, only visually [Prism Dimension Processes / Production] (Clothing).

Another relevant point regarding the Processes dimension concerns revenues, costs and expenses. Some companies are able to record and control inputs, production and outputs, including their expenses. Examples are drugstore and sports shop. In other cases, the elements that also emerged in the interview and which reflect the processes were the supply chain and the entry control of products, such as expiration dates and lot of all marketed products.

All revenues, costs and expenses are registered in separate modules in the system for purposes of monitoring and controlling the performance of the business [Prism Dimension Processes / Planning and Management] (Drugstore).

Register and calculate all revenues, costs and expenses of the business in a notebook. Does not have a management system [Prism Dimension Processes / Planning and Management] (Sport Store).

Prioritize on-time delivery of products [Prism Dimension Processes / Planning and Management] (Department Store).

Control expiration dates and a lot of all marketed products. There is periodic control in the system of all store items [Prism Dimension Processes / Planning and Management] (Drugstore). 
The dimension of Capabilities, although more complex to find in micro and small companies, deals with the differential conditions that the company has and deals with two dynamics, being: people and practices. In terms of capabilities, the reports suggest people's ability to perform the functions. These functions seem to be clear to the company's shareholders, generating an ability to allocate the employee to the activity, task and correct function.

Functions are shared between my wife and me. No employees. But I, besides playing sports regularly, have extensive knowledge of the sector, from its particularities, even the greatest need to serve my public [Prism Dimension Capabilities / People] (Sport Store).

All employees have defined functions, as well as specific training, if needed and are shared in each unit of drugstore, for example: Pharmaceutical and auxiliary [Prism Dimension Capabilities / People] (Drugstore).

As an owner, I have functions that only concern me, such as negotiations with suppliers and problemsolving. Already my employee must worry about generating a good service and for this, I always look for courses and training to offer her [Prism Dimension Capabilities] (Clothing).

I am looking for a job that will enable me to work under pressure. Sebrae always offers refresher courses, and I as trade association president, I always offer my staff to do them [Prism Dimension Capabilities / People] (Department Store).

A second point of the Capabilities dimension deals with the activity practices, according to the PP. The clear point of practice is to create a capability through training, courses, lectures and learning. These activities outside the company seem to help build a more business-oriented employee, strategy and work-life dynamics.

We offer adequate guidance to our customers, regarding the use of all products sold, as well as their specifics [Prism Dimension Capabilities / Practices] (Sport Store).

Collaborators need periodically to participate in training, courses and lectures. As well as, improvement in treatment [Prism Dimension Capabilities / Practices] (Drugstore).

Collaborators often participate in courses and lectures offered by the city's Commercial Association [Prism Dimension Capabilities / Practices] (Department Store).
They often take courses and training with the industries served by the apparel faction [Prism Dimension Capabilities / Practices] (Apparel Faction).

Finally, the last dimension deals with the Contribution of Stakeholders, seeking to answer the following question: What stakeholder contributions the company wants to maintain and develop these capabilities? For Silva et al. (2013, p. 142),

[...] the stakeholder contribution acknowledges the fact that the organization must deliver value to stakeholders since stakeholders must also contribute to the organization.

Some companies showed some contributions from the stakeholder to the business, in terms of the variables clients, suppliers, partners and employees. The following observations support this dimension:

Our company expects as the contribution of our clients their return for new and future purchases, as well as, an indication of new customers [Dimension of the Prism Contribution of Stakeholder] (Sport Store).

As a contribution to our company, we (owner couple) intend to offer all our dedication to the future and growth of the business, as well as, we intend to make new investments [Dimension of the Prism Contribution of Stakeholder] (Clothing).

We hope as a contribution to our company the dedication, punctuality, professionalism and commitment on behalf of our employees so that all the needs of our clients are met [Dimension of the Prism Contribution of Stakeholder] (Department Store).

Our group expects how suppliers' contribution, the best price, punctuality in delivery and partnership for our joint growth [Dimension of the Prism Contribution of Stakeholder] (Drugstore).

The drugstore and clothing company showed some interesting data within the contribution facet, showing guidelines for accounting profit and for the search for the elaboration and implementation of cash flow within the company. The drugstore, because it is part of a network and supposed to be more organized, works with the calculation of the profit through ERP system, being transmitted and updated to all other units. The apparel faction periodically calculates the profit and reserves for reinvestment in the business. In addition, in terms of cash flow, companies seek to make contingency reserves, structure cash flow control and calculate all investments already made.

The calculation of the profit is realized in the system and redistributed in each unit for investment purposes [Dimension of the Prism Contribution of Stakeholder/profit] (Drugstore). 
We calculate profit periodically and make reserves for reinvestment in the business, such as the construction of the shed and purchase of new machines [Dimension of the Prism Contribution of Stakeholder/profit] (Apparel Faction).

We make financial reserves periodically, according to an established percentage. Cash flow is strictly utilized through a complete financial management and investment monitoring system, as well as monitoring expected returns [Dimension of the Prism Contribution of Stakeholder/Cash flow] (Drugstore).

We make contingency reserves, cash flow control and calculate all investments made [Dimension of the Prism Contribution of Stakeholder/Cash flow] (Apparel Faction).

An additional and innovative point of this work was the question about of Performance and how companies deal with the issue of desirable results for shareholders. For Landivar et al. (2013, p. 118 and p. 122) there are two performance evaluations. First, the managerial performance that aims to "[...] evaluate the relative efficiency of the performance of a productive system with others of similar technological characteristics" (benchmarks), based on the analysis of multiple inputs and products. Second, there is an operational performance that " [...] seeks to measure performance at the operational level when an analytical development that achieves process behaviour to an acceptable degree is not possible".

Two performance indicators emerged as the results of interviews with companies. The first concerns sales volume. Respondents monitor their performance through sales achieved. The fundamental point of this finding is the lack of the cost element within the accounting formula to reach a conclusion of loss or profit from the sale. Therefore, although there is a quest to monitor their performance, the sale is not the ideal indicator, but the contribution of the sale to the profit.

Second, a performance indicator that emerged during the survey was the default rate observed by the respondents. In this index, companies seek to monitor the extent to which the indices of nonpayment and future expectation of receipt are organized since the lack of payment should be registered in the accounting reports as losses. Examples of these two performance elements are:

Sales Indicator, compared to the previous month [Performance] (Sport Store).

Monthly sales indicator [Performance] (Department Store).
Monthly sales indicator [Performance] (Clothing).

Indicator of revenue, lack of payments and productivity [Performance] (Apparel Faction).

Indicators of profitability, lack of payments and sales are monitored [Performance] (Drugstore).

\section{Final considerations}

In this article, the most relevant works of the literature on the topic of PP are organized, advancing in the literature on bibliometric works by Grzebieluckas et al. (2008), Faro \& Silva (2008) and Silva \& Souza-Coelho (2007). From the multiple case study research, asking the owners about the use of the different dimensions of PP, we verified that SMEs use the tool in terms of stakeholders, capabilities, strategies and processes.

Overall, some theoretical and practical considerations about PMS in SME can be showed. First, bibliometric studies have gained space and organize literature around a specific topic (see, for example, Faro \& Silva, 2008; Grzebieluckas et al., 2008). In this article, a systematic review of the literature on the PP showed that the work of Neely et al. (2005) is a fundamental point for increasing the discussion on how to use performance evaluation. The authors discuss the state of the art of PMS, presenting a research agenda for continuity in the theme. In addition, a major contribution is the definition of the concept of performance measurement, defined as " $[\ldots]$ the process of quantifying the effectiveness and efficiency of an action" (Neely et al., 2005, p. 1229).

Second, the applicability of PP in SMEs showed significant results. The SMEs have difficulties and limitations of observing what the strategy is in a global way, to consider which indicators can be used for measurement and how to apply them. In Neely et al. (2001), there is a misunderstanding as to the correct timing of formulating company strategies, which are usually drawn in the foreground and after structuring, performance measures are established. However, the favourable context for the implementation of an PMS in SMEs has helped them to better manage uncertainties, to innovate in their products or services, as well as to sustain processes that generate changes and evolutions (Garengo et al., 2005). Thus, this finding was made clear in interviews.

The third relevant contribution of the PP to SMEs, in the companies studied, concerns the low Contribution of Stakeholders to business. This question seeks to understand what contributions the company wants from stakeholders to maintain and develop those capabilities. Many of the interviewees had difficulty observing how they can contribute to the organization's business. While many managers want the most out of 
the business, when placed in the opposite position, they have had difficulty explaining how they can help in the development of their company.

Fourth, the interviews evidenced a strong emphasis by the owners on the sales volume of the business and less on calculating in detail the net or gross profit of the organization. This point can generate misinformation about how the organization is in terms of financial return. In addition, this analysis from a single perspective may be imprecise (Najmi et al., 2012), because it is not known if the strategies are being applied well, since a rise in sales alone may not necessarily be accompanied by profit.

Future research can implement the PP model in other SMEs. Neely et al. (2001) applied the model to large for-profit (e.g. DHL international shipments) and non-profit (e.g. charitable organizations). In some cases the application was successful and in others, as in the latter case, it was not possible to identify success factors. In this line of reasoning, other segments of SMEs may be useful and present particularities relevant to discuss the applicability of PP.

Another type of research proposed is to address PMSs in SMEs, such as the PMS for SMEs developed by Cocca \& Alberti (2010), OPM (Chennell et al., 2000). Researchers can compare results of efficiency and results of PP implementation correlated with objective and financial performance metrics. Still, future research can compare the results generated by the Balanced Scorecard, the CANVAS Business Model Generation with the findings of the PP. These comparisons can validate and facilitate the use of a framework more suited to the reality of the organizations in question.

\section{References}

Adams, C., \& Neely, A. (2000). The performance prism to boost M\&A success. Measuring Business Excellence, 4(3), 19-23. http://dx.doi.org/10.1108/13683040010377818.

Baines, T. S., Lightfoot, H. W., Evans, S., Neely, A., Greenough, R., Peppard, J., Roy, R., Shehab, E., Braganza, A., Tiwari, A., Alcock, J. R., Angus, J. P., Bastl, M., Cousens, A., Irving, P., Johnson, M., Kingston, J., Lockett, H., Martinez, V., Michele, P., Tranfield, D., Walton, I. M., \& Wilson, H. (2007). State-of-theart in product-service systems. Proceedings of the Institution of Mechanical Engineers. Part B, Journal of Engineering Manufacture, 221(10), 1543-1552. http:// dx.doi.org/10.1243/09544054JEM858.

Basso, L. F. C., \& Pace, E. S. U. (2003). Uma análise crítica da direção da causalidade no Balanced Scorecard. Revista de Administração de Empresas, 2(1), 1-21. http://dx.doi.org/10.1590/S1676-56482003000100012.

Bititci, U. S., Carrie, A. S., Turner, T. J., \& Lutz, S. (1998). Integrated performance measurement systems: implementation case studies. In U. S. Bititci \& A. S.
Carrie (Eds.), Strategic management of the manufacturing value chain (pp. 177-186). Dordrecht: Kluwer Academic. http://dx.doi.org/10.1007/978-0-387-35321-0_20.

Bourne, M., Mills, J., Wilcox, M., Neely, A., \& Platts, K. (2000). Designing, implementing and updating performance measurement systems. International Journal of Operations \& Production Management, 20(7), 754771. http://dx.doi.org/10.1108/01443570010330739.

Bourne, M., Neely, A., Platts, K., \& Mills, J. (2002). The success and failure of performance measurement initiatives: perceptions of participating managers. International Journal of Operations \& Production Management, 22(11), 1288-1310. http://dx.doi. org/10.1108/01443570210450329.

Braz, R. G. F., Scavarda, L. F., \& Martins, R. A. (2011). Reviewing and improving performance measurement systems: an action research. International Journal of Production Economics, 133(2), 751-760. http://dx.doi. org/10.1016/j.ijpe.2011.06.003.

Chennell, A., Dransfield, S., Field, J., Fisher, N., Saunders, I., \& Shaw, D. (2000). OPM: a system for organisational performance measurement. In Proceedings of the Performance Measurement: Past, Present and Future Conference. Cambridge: University of Cambridge.

Chillida, J. J. C. (2009). Performance Prism, a new approach to corporate social responsibility (Master thesis). Aarhus School of Business, Aarhus University, Denmark.

Choong, K. K. (2013). Understanding the features of performance measurement system: a literature review. Measuring Business Excellence, 17(4), 102-121. http:// dx.doi.org/10.1108/MBE-05-2012-0031.

Cocca, P., \& Alberti, M. (2010). A framework to assess performance measurement systems in SMEs. International Journal of Productivity and Performance Management, 59(2), 186-200. http://dx.doi.org/10.1108/17410401011014258.

Cross, K. F., \& Lynch, R. L. (1990). Managing the corporate warriors. Quality Progress, 23(4), 54-59.

Curtis S, Gesler W, Smith G, Washburn S. Approaches to sampling and case selection in qualitative research: examples in the geography of health. Social Science \& Medicine 2000; 50(7-8): 1001-1014. http://dx.doi. org/10.1016/S0277-9536(99)00350-0. PMid:10714922.

Dixon, J. R., Nanni, A. J., \& Vollmann, T. E. (1990). The new performance challenge: measuring operations for world class competition. Homewood: Dow Jones-Irwin.

Faro, M. C. S. C., \& Silva, R. N. S. D. (2008). A natureza da pesquisa em contabilidade gerencial-análise bibliométrica de 1997 a 2007 nos principais periódicos internacionais. In Anais do XXXII Encontro da ANPAD. Rio de Janeiro: ANPAD.

Garengo, P., Biazzo, S., \& Bititci, U. S. (2005). Performance measurement systems in SMEs: a review for a research agenda. International Journal of Management Reviews, 7(1), 25-47. http://dx.doi.org/10.1111/j.14682370.2005.00105.x. 
Gosselin, M. (2005). An empirical study of performance measurement in manufacturing firms. International Journal of Productivity and Performance Management, 54(5-6), 419-437. http://dx.doi.org/10.1108/17410400510604566.

Govindarajan, V. (1984). Appropriateness of accounting data in performance evaluation: an empirical examination of environmental uncertainty as an intervening variable. Accounting, Organizations and Society, 9(2), 125-135. http://dx.doi.org/10.1016/0361-3682(84)90002-3.

Grzebieluckas, C., Campos, L. M. D. S., Marinho, S. V., \& Selig, P. M. (2008). O perfil da produção acadêmica em Contabilidade e Custos Ambientais no período de 1996 a 2007: um estudo bibliométrico. In Anais do XXXII Encontro da ANPAD. Rio de Janeiro: ANPAD.

Hopwood, A. G. (1972). An empirical study of the role of accounting data in performance evaluation. Journal of Accounting Research, 10, 156-182. http://dx.doi. org/10.2307/2489870.

Hudson, M., Smart, A., \& Bourne, M. (2001). Theory and practice in SME performance measurement systems. International Journal of Operations \& Production Management, 21(8), 1096-1115. http://dx.doi.org/10.1108/ EUM0000000005587.

Kaplan, R. S., \& Norton, D. P. (1992). The balanced scorecard: measures that drive performance. Harvard Business Review, 70(1), 71-79. PMid:10119714.

Kaplan, R. S., \& Norton, D. P. (2001). Transforming the balanced scorecard from performance measurement to strategic management: part I. Accounting Horizons, 15(1), 87-104. http://dx.doi.org/10.2308/acch.2001.15.1.87.

Landivar, C. G. P., Sproesser, R. L., \& dos Santos, A. B. (2013). Modelos de avaliação de desempenho para terminais intermodais de transbordo de grãos. Revista Gepec, 17(1), 116-131.

Lebas, M. J. (1995). Performance measurement and Performance management. International Journal of Production Economics, 41(1-3), 23-35. http://dx.doi. org/10.1016/0925-5273(95)00081-X.

Liu, J., Love, P. E., Smith, J., Regan, M., \& Palaneeswaran, E. (2015). Review of performance measurement: implications for public-private partnerships. Built Environment Project and Asset Management, 5(1), 35 51. http://dx.doi.org/10.1108/BEPAM-12-2013-0070.

Melnyk, S. A., Bititci, U., Platts, K., Tobias, J., \& Andersen, B. (2014). Is performance measurement and management fit for the future? Management Accounting Research, 25(2), 173-186. http://dx.doi.org/10.1016/j. mar.2013.07.007.

Muylaert, C. J., Sarubbi, V., Jr., Gallo, P. R., \& Rolim, M. L., No. (2014). Entrevistas narrativas: um importante recurso em pesquisa qualitativa. Revista da Escola de Enfermagem da USP, 48(2), 184-189. http://dx.doi. org/10.1590/S0080-623420140000800027. PMid:25830754.

Najmi, M., Etebari, M., \& Emami, S. (2012). Framework to review performance prism. International Journal of
Operations \& Production Management, 32(10), 11241146. http://dx.doi.org/10.1108/01443571211274486.

Najmi, M., Rigas, J., \& Fan, I.-S. (2005). A framework to review performance measurement systems. Business Process Management Journal, 11(2), 109-122. http:// dx.doi.org/10.1108/14637150510591129.

Neely, A. (1999). The performance measurement revolution: why now and what next? International Journal of Operations \& Production Management, 19(2), $205-$ 228. http://dx.doi.org/10.1108/01443579910247437.

Neely, A. (2007). Business performance measurement: unifying theories and integrating practice (2nd ed.). Cambridge: Cambridge University Press.

Neely, A. D., Adams, C., \& Kennerley, M. (2002). The Performance Prism: the scorecard for measuring and managing stakeholder relationships. London: Financial Times/Prentice Hall.

Neely, A., Adams, C., \& Crowe, P. (2001). The performance prism in practice. Measuring Business Excellence, 5(2), 6-13. http://dx.doi.org/10.1108/13683040110385142.

Neely, A., Gregory, M., \& Platts, K. (1995). Performance measurement system design: a literature review and research agenda. International Journal of Operations \& Production Management, 25(12), 1228-1263. http:// dx.doi.org/10.1108/01443579510083622.

Neely, A., Gregory, M., \& Platts, K. (2005). Performance measurement system design: a literature review and research agenda. International Journal of Operations \& Production Management, 25(12), 1228-1263.

Norreklit, H. (2000). The balance on the balanced scorecard a critical analysis of some of its assumptions. Management Accounting Research, 11(1), 65-88. http:// dx.doi.org/10.1006/mare.1999.0121.

O’Boyle, I., \& Hassan, D. (2013). Organizational performance management: examining the practical utility of the performance prism. Organization Development Journal, 31(3), 51-58.

Pun, K. F., \& White, A. S. (2005). A performance measurement paradigm for integrating strategy formulation: a review of systems and frameworks. International Journal of Management Reviews, 7(1), 49-71. http://dx.doi. org/10.1111/j.1468-2370.2005.00106.x.

Reame, E., Jr., \& Reame, G. H. (2007). A aplicabilidade do balanced scorecard e do desempenho prism como modelos de sistemas de medição de desempenho organizacional. Interface Tecnológica, 4(1), 43-50.

Rompho, N. (2011). Why the balanced scorecard fails in SMEs: a case study. International Journal of Business and Management, 6(11), 39-46. http://dx.doi.org/10.5539/ ijbm.v6n11p39.

Santos, R. N. (2004). Produção científica: por que medir? O que medir? Revista Digital de Biblioteconomia e Ciência da Informação, 1(1), 22-38. http://dx.doi. org/10.20396/rdbci.v1i1.2087. 
Seawright, J., \& Gerring, J. (2008). Case selection techniques in case study research a menu of qualitative and quantitative options. Political Research Quarterly, 61(2), 294-308. http://dx.doi.org/10.1177/1065912907313077.

Severgnini, E., Galdamez, E., \& Moraes, R. (2017). Satisfaction and contribution of stakeholders model from Performance Prism. Brazilian Business Review, 15(2), 120-134. http://dx.doi.org/10.15728/bbr.2018.15.2.2.

Silva, A. B., Godoi, C. K., \& Bandeira-De-Mello, R. (2010). Pesquisa qualitativa em estudos organizacionais: paradigmas, estratégias e métodos. São Paulo: Saraiva.

Silva, R. N. S., \& Souza-Coelho, P. S. (2007). Um estudo exploratório sobre as metodologias empregadas em pesquisas na área de contabilidade no EnANPAD. Revista Contemporânea de Contabilidade, 4(8), 139-159.

Silva, S. D., Jr., Luciano, E. M., \& Testa, M. G. (2013). Contribuições do Modelo de Medição de Desempenho Organizacional da Desempenho Prism ao Balanced Scorecard: um estudo sob a perspectiva dos stakeholders. Revista de Ciências da Administração, 1(1), 136-153. http://dx.doi.org/10.5007/2175-8077.2013v15n37p136.

Silvi, R., Bartolini, M., Raffoni, A., \& Visani, F. (2015). The practice of strategic performance measurement systems: models, drivers and information effectiveness. International Journal of Productivity and Performance Management, 64(2), 194-227. http://dx.doi.org/10.1108/ IJPPM-01-2014-0010.

Singh, K., \& Weligamage, S. (2010). Thinking towards stakeholder satisfaction in higher education: an application of performance prism. In Proceedings of the 1st International Conference on Business and Information. Sri Lanka: University of Kelaniya.

Smulowitz, S. (2015). Evidence for the performance prism in higher education. Measuring Business Excellence, 19(1), 70-80. http://dx.doi.org/10.1108/MBE-11-2014-0043.

Stake RE. The case study method in social inquiry. Educational Researcher 1978; 7(2): 5-8. http://dx.doi. org/10.3102/0013189X007002005.

Tangen, S. (2004). Performance measurement: from philosophy to practice. International Journal of Productivity and Desempenho Management, 53(8), 726-737.

Taticchi, P., Balachandran, K. R., Botarelli, M., \& Cagnazzo, L. (2008). Performance measurement management for small and medium enterprises: an integrated approach. Journal of Applied Management Accounting Research, 6(2), 57-71.

Taticchi, P., Tonelli, F., \& Cagnazzo, L. (2010). Desempenho measurement and management: a literature review and a research agenda. Measuring Business Excellence, 14(1), 4-18. http://dx.doi. org/10.1108/13683041011027418.

Taylor, A., \& Taylor, M. (2014). Factors influencing effective implementation of performance measurement systems in small and medium-sized enterprises and large firms: a perspective from Contingency Theory. International Journal of Production Research, 52(3), 847-866. http://dx.doi.org/10.1080/002075 43.2013 .842023 . 